\title{
Relational Analysis on IPM Practices for Control of Pink Bollworm
}

\author{
Shital Mane*, G. Sriker Reddy and Manisha Lavankar \\ Department of Extension Education, College of Agriculture, Nagpur, India \\ *Corresponding author
}

\section{A B S T R A C T}

\begin{tabular}{|c|}
\hline Keywords \\
\hline $\begin{array}{l}\text { Knowledge, } \\
\text { Adoption, } \\
\text { Significance, } \\
\text { Cotton growers, } \\
\text { Pink bollworm }\end{array}$ \\
\hline Article Info \\
\hline $\begin{array}{l}\text { Accepted: } \\
16 \text { November } 2020 \\
\text { Available Online: } \\
10 \text { December } 2020\end{array}$ \\
\hline
\end{tabular}

\section{Introduction}

The world textile industries are being ruled by "King Cotton". The antiquity of cotton has been traced to the fourth millennium BC. The fabric pieces from "Mohenjodaro" excavations were found to made up of cotton. For over three thousand's years $(1500 \mathrm{BC}$ to 1700 AD) India was recognized as cradle of cotton industry. India was country in the world to domesticate cotton and utilize its fibre to manufacture fabric. India is the second largest producer of cotton in the world. India accounts for approximately 25 per cent of world's cotton area and 16 per cent of total cotton production. Maharashtra is the important cotton growing state in India
Cotton is most important cash and fibre crop of Vidarbha grown under diversified condition in the region. The present study on adoption of integrated pest management practices for control of pink bollworm by cotton growers with a sample size of 120 farmers selected from 10different villages of two talukas. The selected variables like ucation, occupation, economic motivation, sources of information and extension participation were positively significant with knowledge, whereas age and farming experience were negatively significant with knowledge and land holding, annual income control of pink bollworm. Whereas education, occupation, farming experience, sources of information, extension participation, economic motivation and scientific orientation were positively significant with the adoption, whereas age was negatively correlated and land holding, area under cotton cultivation and annual income were non-significant relation with the adoption of IPM practices for control of pink bollworm. with 31.33 lakh ha and production of 62.00 lakh bales.

A number of studies have examined the significant economic, environmental and social benefits derived from growing $\mathrm{Bt}$ cotton in India and world, but the studies conducted on farmers knowledge and adoption levels of pink bollworm management practices are less. Through a number of important management technologies are recommended by the researchers and extension workers to obtain maximum profit, measuring the farmers knowledge and adoption level of pink bollworm management practices are important to help them to realize the complete 
yield potential of the crop. The review of literature clearly indicated that not many studies are conducted in this direction. Secondly few cotton growers if adopted the pink bollworm management practices haphazardly without much consideration to the package of practices recommended for the control of pink bollworm in cotton.

\section{Materials and Methods}

The study was conducted in Nagpur district of Maharashtra State. Out of 14 talukas of Nagpur district namely, Hingna and Nagpur (Rural) talukas were purposively selected for the study. Five villages were selected purposively from each taluka considering the maximum area under cotton cultivation. Thus in total, ten villages were taken for the study and a total of 120 respondents were selected. The exploratory research design was used for the study. The data were collected in face-toface situation by the personal interview method with the help of structured interview schedule containing the questions on adoption of integrated pest management practices for control of pink bollworm. The data were tabulated, analyzed and the results were interpreted as on Table 1.

\section{Results and Discussion}

\section{Relational analysis}

It is evident from Table 1 that amongst the personal, socio-economic, communication and psychological characteristics of respondent cotton growers education, occupation and economic motivation found to have positive highly significant correlation with extent of knowledge possessed by the respondents at 0.01 level of probability. Whereas farming experience was negatively significant with knowledge at 0.01 level of probability.

Table.1 Correlation coefficient of selected characteristics of the respondents with their knowledge and adoption of integrated pest management practices

\begin{tabular}{|c|l|c|c|}
\hline Sl. No. & Variables & $\begin{array}{c}\text { Knowledge } \\
\text { "r"values }\end{array}$ & $\begin{array}{c}\text { Adoption } \\
\text { "r" volues }\end{array}$ \\
\hline $\mathbf{1}$ & Age & $-0.2266^{*}$ & $-0.2387^{* *}$ \\
\hline $\mathbf{2}$ & Education & $0.4488^{* *}$ & $0.4676^{* *}$ \\
\hline $\mathbf{3}$ & Occupation & $0.3856^{* *}$ & $0.3161^{* *}$ \\
\hline $\mathbf{4}$ & Land holding & $-0.031^{\mathrm{NS}}$ & $-0.0359^{\mathrm{NS}}$ \\
\hline $\mathbf{5}$ & Area under cotton cultivation & $0.0194^{\mathrm{NS}}$ & $0.0623^{\mathrm{NS}}$ \\
\hline $\mathbf{6}$ & Farming experience & $-0.3789^{* *}$ & $0.4227^{* *}$ \\
\hline $\mathbf{7}$ & Annual income & $0.0983^{\mathrm{NS}}$ & $-0.028^{\mathrm{NS}}$ \\
\hline $\mathbf{8}$ & Sources of information & $0.1765^{*}$ & $0.1918^{*}$ \\
\hline $\mathbf{9}$ & Extension participation & $0.2240^{*}$ & $0.2608^{* *}$ \\
\hline $\mathbf{1 0}$ & Economic motivation & $0.2337^{* *}$ & $0.2301^{* *}$ \\
\hline $\mathbf{1 1}$ & Scientific orientation & $0.1723^{\mathrm{NS}}$ & $0.2452^{* *}$ \\
\hline $\mathbf{1 2}$ & Knowledge & - & $0.7262^{* *}$ \\
\hline
\end{tabular}

** Significant at 0.01 level of probability NS- Non significant

* Significant at 0.05 level of probability

The variable, sources of information and extension participation could establish the positive and significant correlation with knowledge at 0.05 level of probability. 
Whereas, age was negatively significant correlation with knowledge at 0.05 level of probability. The variable, land holding, annual income and scientific orientation did not shown any significant association with knowledge possessed by the respondents. These findings conformity with Reddy (2013), Rathwa (2018) Raviya (2017), Sanjay Kumar (2003) and Bansod (2016).

It is also indicated from Table 1 that amongst the characteristics of respondent education, occupation, farming experience, extension participation, economic motivation and scientific orientation were found to be positively and significantly correlated with adoption of IPM practices by the respondents at 0.01 level of probability. Whereas only one variable namely age found to have negative but significant correlation with adoption of IPM practices by the respondents. Whereas sources of information has positively and significantly correlated with adoption at 0.05 level of probability Therefore, the null hypothesis, was rejected for these characteristics. Knowledge was found to be positive and significantly correlated with adoption of integrated pest management practices for control of pink bollworm by cotton growers at 0.01 level of probability. These findings are in conformity with the findings of Kumar and Dhorey (2017), Himdari (2018), Mandlik (2012), Kajal Bhaltilak (2017) and Raviya (2017).

In the present study, it was concluded that majority of the coconut growers were above 50 years having education between $8^{\text {th }}$ to $12^{\text {th }}$ standard. However, coconut growers gain knowledge in coconut production through their vast experience in coconut cultivation (70 per cent having 17 to 43 years of experience). Hence the observed negatively significant correlation between education and knowledge might be observed as coconut growers gain knowledge due to their experience in coconut cultivation and not due to education.

In general opinion, education of respondents favours the acquisition of knowledge and widens the horizon of knowledge by proper understanding of the importance of coconut production technology by getting exposed to the mass media, social participation and extension contact by them. More land holding and experience in coconut cultivation could also motivate the coconut growers for acquiring the information required.

It was obvious that increase in annual income with availability of land holding, more area under coconut cultivation and proper extension contact encourage the corresponding respondents to adopt the coconut production technology.

\section{References}

Bansod, S. K. 2016. Knowledge and adoption of integrated pest management practices by the brinjal growers. M.Sc. (Agri.)Thesis (Unpub.), Dr.PDKV, Akola.

Himdari Roy, D. M. Mankar, Rohit Shelar, Ravi K. N. Awadhesh Kumar Singh. 2018. Assesing the extent of adoption of improved $\mathrm{Bt}$ cotton cultivation practices by the $\mathrm{Bt}$ cotton growers in Akola district. M.Sc. (Agri.) Thesis (Unpub.), Dr. PDKV, Akola.

Kajal Bhaltilak.2017. Knowledge and adoption of insecticide as per the label claim by cotton growers in Akola Dist. M.Sc. (Agri.) Thesis (Unpub.), Dr. PDKV, Akola.

Kumar P. P. and R. K. Dhorey. 2017. Extent of adoption of farmers about Bt. Cotton practices in Warangal District of Telangana State, Int. J. Curr. Microbiol. App.sci. 6(11):824-829.

Mandlik, S.P.2012.Knowlegde and adoption 
of integrated pest management technology in pigeon pea. M.Sc. (Agri.) Thesis (Unpub.), MKV, Parbhani.

Rathwa,Y.H.2018. Knowledge and attitude of cotton growers towards integrated pest management in Surendranagar district of Gujrat state. M.Sc. (Agri.) Thesis (Unpub.), JAU, Junagadh.

Raviya P. B. 2017. Knowledge and adoption of farmers about cotton production practices recommended by GAU and JAU in Junagadh district. M.Sc. (Agri.)
Thesis (Unpub.), Junagadh Agricultural University, Junagadh.

Reddy, N.P.2013. Knowledge of cotton farmers on health hazards of pesticides in Kurnool district. M.Sc.(Agri.) Thesis(Unpub.), Acharya N.G. Ranga Agricultural University, Hydrabad.

Sanjay kumar.2003.A study of knowledge level of Bt.cotton growers about Bt.cotton cotton. M.Sc. (Agri.) Thesis (Unpub.), Gujarat Agriculture University, Anand.

\section{How to cite this article:}

Shital Mane, G. Sriker Reddy and Manisha Lavankar. 2020. Relational Analysis on IPM Practices for Control of Pink Bollworm. Int.J.Curr.Microbiol.App.Sci. 9(12): 2496-2499. doi: https://doi.org/10.20546/ijcmas.2020.912.295 